Special Issue:

Can the Bureaucracy Contribute to the Democratizaton? 



\title{
Revisiting Bureaucratic Dysfunction: The Role of Bureaucracy in Democratization*
}

\author{
Tobin Im**
}

\begin{abstract}
While many studies have focused on the link between economics and democracy in exploring the strategies adopted by developing countries, they have tended to overlook the role of bureaucracy in democratization. This study seeks the missing link between bureaucracy and democratization. What are the conditions necessary for bureaucracy to facilitate the democratization process of a country? This article begins by briefly reviewing the bureaucracy literature from Max Weber and Karl Marx and then argues that despite its shortcomings, bureaucracy in its Weberian form can facilitate the political democratization of a developmental state. This study concludes that although bureaucracy is often regarded as dysfunctional, it can be instrumental in the democratization process in the context of the developmental state.
\end{abstract}

Keywords: Weberian bureaucracy, democracy, economic development, bureaucratic dysfunction

\section{THE MISSING LINK BETWEEN BUREAUCRACY AND DEMOCRATIZATION}

Many scholars raise the question of what government's role is in a country's economic development, but only a few have researched the relationship between the bureaucracy and democratization. This reflects 'Economy first' which is the typical development strategy that many developing countries adopt, placing an emphasis on economic growth and rarely asking about democracy. Relatively, the relationship between bureaucracy and economic development in developing countries has been studied by Western economists, sociologists, and political scientists. North (1989)

\footnotetext{
* This research is supported by National Research Foundation of Korea (NRF-2014S1A3A2044898).

** "Tobin Im is a professor of the Graduate School of Public Administration and an adjunct researcher of the Korea Institute of Public Affairs at Seoul National University, Korea." E-mail: tobin@snu.ac.kr.
}

Manuscript received December 28, 2016; out for review January 8, 2017; review completed February 24, 2017; accepted February 27, 2017.

The Korean Journal of Policy Studies, Vol. 32, No. 1 (2017), pp. 127-147.

(C) 2017 by the GSPA, Seoul National University 
emphasizes the importance of institutions, such as an efficient judicial system, which can matter in the development of economies. Evans and Rauch (1999) argue in a similar way that an effective and rule-following bureaucracy significantly enhances prospects for economic growth using a sample of 35 developing countries for the 1970 to 1990 period. Haggard (2004) finds that institutions have played a central role in political economic accounts of East Asia's growth, from the developmental state to the microinstitutions of industrial policy. Corruption and its effect on economic growth has also been widely addressed (Mauro, 1995; Shleifer \& Vishny, 1993). Furthermore, recently a consensus has emerged to the effect that not only quantitatively factors like economic growth but also qualitative elements such as quality of life are important characteristics of successful development in developing countries (Sen, 1999).

It is understandable that many developing countries mobilize and dedicate their available resources to economic growth, since almost the entire population lives in poverty. Therefore how to rapidly develop the economy of country is the main concern for many political leaders of developing countries as well as many global Institutes such as the Asia Development Bank and World Bank. Scholars have explored the role that bureaucracy plays in facilitating economic development (Chibber, 2002). The "four tigers'--Singapore, South Korea, Taiwan, and Hong Kong--are well-known cases that help clarify the theoretical concept of bureaucracy in the a full economic developmental model. Ironically, however, politics are minimized or ignored in their case research. For example, in a study of Japan's development, Johnson (1982) stresses that bureaucracy, more precisely, the Ministry of International Trade and Industry, was the driving force behind Japan's economic development. Muramatsu and Krauss (1987), however, criticize Johnson for ignoring the role of politicians in forming the proeconomic growth consensus. Many scholars seem to generally believe that the more democratized a country is, the happier its citizens will be. South Korea is not an exception in this regard. This phenomenon is possibly shown in most of Asian states' context due to the 'Economy first ${ }^{1}$ ' strategies.

There is mounting evidence that government bureaucracy is strongly connected to good government performance, which suggests that in less developed countries where democracy is usually not well established, creating a well-functioning bureaucracy can be a prior goal (Cho, Im, et al, 2013). A strong performance on the part of the government is assumed to contribute to better economic performance in a coun-

1. 'Economy first, and politics second' is the typical development strategy that many developing countries adopt. This implies that government prioritizes economic development over any other issues. 
try. This hypothesis is even more plausible when it comes to developmental states such as Singapore, for example.

The economy and politics are like two sides of the same coin because politics is related to the distribution of wealth. Therefore, if we expand the definition of politics as power and allocation of resources, more connections between the two emerge. First, decentralization can be considered part of the political democratization process to the extent that an authoritarian regime ends up sharing power with local governments. In addition, different kinds of decentralization bring different effects. Fiscal decentralization contributes to the economic growth, while political decentralization does not have a significant relationship with economic growth (Rodríguez-Pose and Ezcurra, 2011; Im, 2010). Second, in a broad context, the allocation process can be part of political democratization. If the allocation process is unpredictable or unstable, political democratization can be beset by corruption. Although political modernization can diminish corruption, corruption is still widely considered to be synonymous with bureaucracy, not democracy. Many researchers, however, emphasize studies that point to the negative effects of decentralization and single out bureaucrats as the main hindrance to the economy growth or democratization.

For example, Hanna Bäck and Axel Hadenius (2008) question how democratization affects state administrative capacity by using the time series method. Their conclusion is that there is a curvilinear (J-shaped) relationship between the two factors. In other words, the effect of democratization on state capacity is negative at low values of democracy, nonexistent at median values, and strongly positive at high democracy levels. However, if we examine the reverse relationship with this statistical method, using the definition of bureaucracy rather than an ambiguous concept of state capacity as a variable, the question becomes whether the bureaucracy affects democratization.

In that sense, this paper examines a different version of this question, exploring whether and under what conditions the bureaucracy can be an independent variable in the production of democracy. Acknowledging the current status of research on this topic, this study argues that there is a relationship between bureaucrats and the democratization of a country. How can a bureaucracy lead to democratization in a country? What are the conditions necessary for bureaucracy to facilitate the democratization process of a country? These are examples of the kind of questions that this study takes up. 


\section{CLARIFICATION OF CONCEPTS: BUREAUCRACY AND DEMOCRACY}

Before diving into the argument, it is necessary to look into the meanings of the key concepts, since they are used in various senses.

\section{Bureaucracy and Bureaucratization}

"Bureaucracy" is a term that has been used in many different senses in Europe in particular (Albrow, 1978). Among them, we highlight the sense of it as "rule by officials." From the bureaucratic-polity perspective, rule by officials is viewed as a political system that is dominated by officials. Laski defines bureaucracy as "a system of government the control of which is so completely in the hands of officials that their power jeopardizes the liberties of ordinary citizens" (1930, p 70-74) Herman Finer views bureaucracy as "government by officials" (Albrow, 1970, p.92), and Lasswell and Kaplan also define bureaucracy as "the form of rule in which the elite is composed of officials" (1950, p.209). From the bureaucrats-in-power perspective, officials are understood as the ruling class. Sharp refers to bureaucracy as "the exercise of power by professional administration" (1927, p394), which in turn leads Brecht (1954) to question the definition of bureaucracy as "government by officials" and embrace instead the idea of it as "office-holders who exercise power."

According to Max Weber, whose theory of bureaucracy is well known, the modern form of bureaucracy can arise only when legal authority is institutionalized. Authority, categorized into three types, charismatic, traditional, and legal, in the Weberian sense of the term, has a special connotation to the effect that subordinates in a hierarchy "accept" it. Thus the primitive bureaucracies that stem from charismatic authority or traditional authority are quite different from modern bureaucracies. Until the end of eighteenth century, charismatic or traditional authority dominated the organization of political and social groups of the feudal classes in Western culture. Society was stratified according to family groups. However, the separation of business from the household that began with the shift from an agricultural self-sufficient economy to an industrial one changed the makeup of the classes. By the mid-nineteenth century, the modern bureaucratic form of organization was prevalent in the industrialized world. The bureaucratic structure, Weber (1968) argues, emerges as an efficient way of organizing humans to achieve a goal. Modern bureaucracy coupled with legal authority required the democratization of government. Rationalization of the society is also strongly associated with democratization. It is this particular aspect 
of Weber's thesis that this study draws on.

Weber (1968) emphasizes that bureaucratization means intensive qualitative expansion of administrative tasks, not just a quantitative increase in the size of an organization. According to Weber, "the fully developed bureaucratic apparatus compares with other organizations exactly as does the machine with non-mechanical modes of production. Precision, speed, knowledge of the files, continuity, discretion, unity, strict subordination, reduction of friction and material and personal costs--these are raised to the optimum point in the strictly bureaucratic administration, and especially in its monocratic form" (1978, p 973).

Despite the suggestion that bureaucracy possesses a "rational" character, much literature on bureaucracy is grounded in Max Weber's ideal typology. Weber clearly defines the principle of modern bureaucracy as the principle of an official jurisdictional area, which is generally ordered by rules, by laws or administrative regulations. In order to function, the authority to give commands and methodical provision are needed (Weber, 1968). Bureaucracies are organizations with specific functional attributes: a large size; a graded hierarchy; a formal, rule-based administration; a; standardized procedures; a reliance on written documentation; and a clear functional division of labor into specialized tasks (Olsen, 2006; Gerth \& Mills, 1946). They are large normative structures in which authority reigns. The rational-legal political order can be enforced by the authority of the state (Olsen, 2006).

Bäck and Hadenius (2008)'s study on the relationship between democracy and state capacity defines a capacity for public bureaucrats to be able do their job in the best way as a criterion for a functioning state. Their statistical analysis uses measurements of bureaucratic quality and corruption control (as defined by the international country risk guide) as variables. However, they fail to provide a full theoretical explanation of either of these variables, to which they give equal weight. In this study, I define bureaucracy as a system in which employees are salaried, technically trained, career appointed, and assigned stated duties that require expert knowledge for them to be able to carry them out (Etzioni-Halevy, 2010) and who advance in the organization according to a principle of meritocracy. Today, as Stephen Miller (1978) notes, bureaucracy has come to stand for all that is wrong with modern world. It has been made a great target, decried as "headless and soulless," and subject to demands for reform by presidents, public media, citizens, and even academics. Despite negative perceptions of bureaucracy, it is evident that bureaucracy has positive traits: unity and coordination, precision and speed, predictability, obedience, loyalty, impartiality, an institutionalized memory, and continuity across changes in government (Olsen, 2006). 


\section{Democracy and Democratization}

Like the term "bureaucracy," "democracy" is difficult word to define. It is no use defining it in terms of the politics of any particular country (Ryan, 1973), since every country has different political conditions. However, it is worth pursuing the etymological route. "Democracy" is derived from the Greek words "demos" and "kratos." "Demo" means "people" and "kratos" can be translated as "power,' and so the root meaning of democracy is "power of the people." Here, by democracy I refer to political democracy in a liberal sense. In this conception, people must be the master of their fate and be able to determine their affairs at their will. This contrasts with a dictatorship, in which a single person has absolute power over the people. Therefore, simply put, democratization can be defined as allocating power (or authority) to people. People's sovereignty is the key concept.

David Beetham isolates "the core ideas or principles embodied in the historical conception of democracy as 'rule of the people," identifying them as "popular control" and "political equality" (1993, p.6). Hadenius adopts a similar approach and arrives at a conception of political democracy in which public policy is determined by "the freely expressed will of the people whereby all individuals are to be treated as equals" (1992, p.9). Lively (1975) describes the norms dictating inclusive citizenship and political equality, while Holden (1988) equates democracy with popular sovereignty (Saward, 1994). Eva Eztioni-Halevy (2010) defines democracy (or a democratic political structure) as the institutional arrangement whereby two or more organized groups of people participate in a contest for power on the strength of their policies or the image of themselves that they project and whereby they secure their position via a free election in which the whole adult population is able to participate. Satori argues that "democracy is a procedure by which leaders compete in elections for power to govern (1962, pg. 124-127)". In the absence of an election process, the government becomes an authoritarian one. However, although most developing countries have institutionalized elections, these elections have not brought about democratization.

Democratization can also be characterized in terms of where the transformation of political power was initiated. Redford (1969) calls the top-down approach model "overhead democracy." He views bureaucracy as an authority that puts policy that has been crafted by democratically elected branches of government, which are supposed to rely on the principle of law, into effect. For Schumpeter (1956), democracy is a political method, a certain type of institutional arrangement for arriving at a political decision. Therefore, people's participation in the policy-making process is 
important. Democracy, at least in this sense, means that people have the opportunity to accept or reject the individuals who are supposed to govern them. Referendum is a tool to guarantee this minimal power. Transparency is a key to tracking the functioning of democracy.

From a "power" perspective, democracy refers to a change in the way resources are shared. In a participatory democracy, values are shared through citizens' participation. In an electoral democracy, resources are allocated through elections. In a liberal democracy, rights and liberties are allocated to everyone. From a "people" perspective, democracy is about establishing channels for equality. Economic democracy is about equality in the production process. Anyone who participates in this process has a right to a share of what is produced and a say in the decision-making process. In social democracy, the government takes responsibility for providing welfare (social services). In political democracy, the power of the state is equally shared by the citizens.

In a broad context, factors that facilitate the distribution of resources and power and that encourage participation can be considered part of democratization as well. In the South Asian context, this includes the adoption of Western democratic theory, the introduction of local self-government, and e-government.

\section{THE AUTONOMY OF BUREAUCRACY}

Bureaucracy takes different forms and play different roles in different cultural context (Im, 2014). In a country where democratization has not been fully installed, it can work as a positive driver of economic, political, and social democracy, especially in developing countries where the private sector has not yet wholly developed.

\section{From a Weberian Perspective}

For Max Weber, bureaucracy is a neutral tool that serves political power. He presupposes the principle of subordination of administration, that is, bureaucracy, to politics (Timsit, 1991). The division of labor between politicians and bureaucrats is clear; politics takes care of policy formulation, while the role of bureaucrats is limited to implementation, through which they gain knowledge. Such accumulated knowledge becomes a state capacity, a dominant power factor in bureaucratic administration. From this perspective, Larry Preston (1987) argues that bureaucracy supports individual freedom because a structured system creates opportunity in which to make choices, learn, create, and achieve a higher purpose; bureaucracy can serve to moti- 
vate bureaucrats. Bureaucrats concretize subgoals in the process of implementing politicians' goals.

Thus, a concept of bureaucratic power arises naturally. Government is where bureaucrats' collected knowledge is concentrated, and it is the agent in the division of labor that can coerce all other agents in society (Dahl \& Lindblom, 1953). Governments make crucial contributions to society and are thus "a necessary evil" (Wills, 2000). Paul du Gay contends that bureaucracy allows the democratic state to act forcefully, morally, and accountably; however, as Carl J. Friedrich notes, bureaucracy is "the core of modern government," and the success of democracy itself depends on a successful bureaucracy (1963, pg.463)

If the power of a bureaucracy expands far enough, we arrive at what is often called the "administrative state." The autonomy of a bureaucracy is problematic in the administrative state and can lead to the kind of dysfunction that sociologists in the 1960s described in which bureaucrats are too busy protecting themselves to serve the people. These days, since knowledge is part of administrative capacity, it is commonly understood that transparency and trust is possible if appropriate public officials are recruited and promoted.

\section{From a Marxist and Neo-Marxist Perspective}

In the Marxist model, there is an antagonistic relationship between the bourgeoisie and proletariat regarding the distribution of surplus in society. Because the mode of production in capitalist society is private ownership, commodity production proliferates under it, and labor becomes increasingly fragmented. The bourgeoisie monopolizes the tools of production to maximize its profits by exploiting the proletariat's labor. The surplus enriches the bourgeois class at the expense of the proletariat.

The state from the Marxian perspective is a governing body reflecting the dominant social force of a society. Marxists view the role of the state as uniting the divided parts of the social order by organizing the capitalists and disorganizing the working class. Marx saw the development of bureaucracy in government as the counterpart of bureaucracy in private sector. The owners of private companies heavily dominate the capitalist state. According to Marx, the bureaucracy is an "appalling parasitic body" for the proletariat, but at the same time, it is the most powerful instrument of administration that exploits class.

From that argument, Neo-marxists question the classical Marxist assumption that the state is just a tool of bourgeoisie by homing in on the role of bureaucracy. Because the state is more than the "government." Stepan (1978) argues that state is an administrative, legal, bureaucratic, and coercive system. Therefore, the state can- 
not be understood only in terms of class relations and class struggles. The state is also an independent organization with its own internal structure and its own interests (Skocpol, 1999). According to Skocpol (1999), the state is an organic entity and very much an autonomous unit. Neo Marxists argue that the state's interest is not only classical Marxist's idea of economical class, but also expands to various social factors such as gender, age group and ethnic background which can affect class structure.

Neomarxism sheds light on a new dimension of the state that emerges with authoritarian states across the Latin America: the ability of them to be sustained at least partially by the rent-seeking behavior of bureaucrats. Krasner (1984) argues that since the state is an autonomous actor in the political system, public officials act as more than referees. Government institutions do have an autonomous decision-making capacity (Truman, cited in Almond 1988).

Etzioni-Halevy (2010) concludes that bureaucrats around the world not only help politicians make policy but also counter their power and serve as bulwark against corruption. Evans (1985) argues that the efficacy of the developmental state depends on a meritocratic bureaucracy with a strong sense of corporate identity and a dense set of institutionalized individuals similar to private elites. He also argues that Weberian characteristics significantly enhance prospects for economic growth and that therefore building better bureaucracies is necessary. Evans regards the state as a set of organizations invested with the authority to make binding decisions for people and organizations that are located in a particular territory and to implement these decisions using force if necessary. Again, the autonomy of bureaucracy is an important factor.

\section{BUREAUCRATIC DYSFUNCTION AND BUREAUCRATS TOOLS FOR COUNTERBALANCING DICTATORSHIP}

Civil servants are a feature in most developing countries. At first, collaborators with the dictator are most likely to take government jobs, but as time passes, merit based recruitment is gradually introduced, at least partially. Even though some employees are highly corrupt, some members of this group acquire a level of professionalism that enables them to take action against the dictatorship. Their accumulated professionalism becomes the basis of autonomy.

National planning can thus be a potential tool in facilitating the political democratization of developing countries. For example, economic planning is a prevalent economic growth strategy in developing countries; such planning establishes that a spe- 
cific level of national economic or industrial development will be reached within a period of five years (or two five-year plans and so on). This method was first used in the Soviet Union (1928-1991) but later in other socialist states such as Argentina (1946-1955), Bhutan (1961-), China (1953-), Ethiopia (1957-), India (1947-), Nepal (1956-), Pakistan (1955-1998), Romania (1951-1989), South Korea (1962-1996), Vietnam (1958-), and Malaysia (1956-1960) have used or are still using this method for their economic growth. The success of a five-year plan requires strong government leadership to implement policy.

In case of South Korea, Park Jung-hee, who led the May 16 military coup in 1961, introduced a five-year plan in order to boost the country's socioeconomic status after the Korean War. It was the first long-term strategic economic development plan in South Korea, and it was renewed until 1996. Before this economic development plan was established, Korea's economy largely depended on U.S. aid and its planning on foreign experts. The first phase of economic development plan (1961-1965), 84 percent of total foreign capital was public sector funds in the form of bilateral loans that were directly made to the government. This allowed the government to lead the development rather than the private sector (Stallings, 1990).

In order to implement plan more efficiently, the president established an economic planning board, which remained in place until 1994. It was new type of government agency comprised of 4 bureaus--a general planning bureau, a budget bureau, a material resources mobilization planning bureau, and a statistics bureau--19 divisions, and 228 employees. The ability of the economic planning board to recruit elites, its power to implement policy, and its adherence to procedure and the rule of law allowed it to facilitate political democracy (Choi, 1987).

Bureaucrats who worked at the board were members of the elite who were selected for the job after having passed a relatively difficult exam. Being guaranteed lifelong employement made them feel secure, which allowed them to assume a longterm perspective on their work. Bureaucrats who worked at other agencies during this time were not fundamentally different from those who worked at the economic board in this regard. This does not mean that there were nocorrupt and incompetent bureaucrats. Many of them in fact collaborated with the Japanese colonial regime. These facts do not match as Bäck and Hadenius (2008)'s prediction that a high level of bureaucracy correlates with a low level of corruption.

When bureaucrats acquire power vis-a-vis the regime, they start enjoying a certain autonomy. This power results from the "establishment of a substantive consensus among elites concerning the rules of the democratic game and the worth of democratic institutions" in the democratization process (Grugel \& Riggirozzi, 2012; Burton et al., 1992. P.3). It is natural that once a bureaucracy becomes large bureaucrats come 
to share a sense of solidarity among themselves and are given to exercise power by bending rules to protect themselves if necessary. Bureaucracy in a democratic country can thus have negative effects.

The most common criticism of Weberian bureaucracy pertains to bureaucratic dysfunction such as is manifested in adherence to rules that lead to delay, red tape, unresponsiveness, avoidance of responsibility, power seeking, and corruption (Dimock 1959). Many scholars in Western countries have analyzed the negative consequences of bureaucracy, including Selznick, Croizer, Gouldner, Merton, and Blau.

Merton (1940), for example, carries out a functional analysis of bureaucracy and argues that it tends foster goal displacement, by which he means that strict obedience and conformity to norms and rules may lead to a situation where adherence to procedure becomes an end in itself, inhibiting the ability of the organization to achieve its goals. Merton calls this consequence "latent dysfunction" (Edward, 1984; Merton, 1940, p.26). Bureaucrats use their capacity as a tool to sustain their position rather than to improve performance.

However, this kind of bureaucratic dysfunction can also have positive effects in developing countries. The main problem of developing countries is how to restrain dictators from exercising arbitrary power, from the politician or dictator (or president)'s perspective, bureaucracy can be a barrier to their desire to make unpredictable decisions that serve their interests.

Politicians prefer to adopt short-term plans in order to enjoy maximum benefit while they are in office. Several researchers have pointed out that formal bureaucratic procedures, sometimes described as red tape, can act as safeguard to ensure accountability, predictability, and fairness in decisions (Goodsell, 1985; Benveniste,1983; Kaufman, 1977; Thomson, 1975). It provides citizens with protection against the arbitrary and capricious exercise of power not only by officials but also politicians and even dictators. Therefore, bureaucratic procedures can serve as a constraint on everyone, including a dictator, which could possibly lead to political democratization. In the following, I explore the principal bureaucratic mechanisms that could promote democratization.

\section{Expertise}

Bureaucratic autonomy comes from expertise. Bureaucratic officials have the opportunity to be trained in a field of specialization, and their knowledge of rules of the organization they work for represents a special technical expertise (Weber, 1968). In the case of South Korea, since the task of the economic planning board was to manage foreign aid and capital, they were presented with opportunities to gain finan- 
cial knowledge. This is the reason why professors of economics were made ministers of the board, while former generals largely made up the ministers in other agencies. The presidents knew that economic policy could not be handled by nonexperts.

However, appointing economists to minister positions on the board was not sufficient to run it. Korea's five-year economic development plan was renewed seven times, and that long-term development planning required hiring individuals who would stay in the job for a significant period of time. Bureaucrats also were able to acquire knowledge by studying abroad and attending international conferences or meetings. Well-educated and highly experienced officials, scholars, and business leaders collaborated with the board, contributing to the accumulation of expert knowledge. The board's bureaucrats thus developed an administrative capacity that made them superior to other politicians and stakeholders.

In addition, an open merit system made the organization relatively autonomous and enabled it to avoid becoming beholden to special interests. Therefore, its bureaucrats had the ability to say no to politicians, private economic interest groups, and other stakeholders who lacked their expertise.

The economic planning board was not a special case. Other government agencies in Korea during this period were similarly structured, but the difference between them was the eliteness associated with the economic planning board. Anyone could apply for a public official position, but if an individual earned higher marks on the open examination, he or she could start at a higher level. The recruitment system of bureaucrats relied on the national civil service exam, which was highly competitive, and earning a high mark on it it was sufficient to give those who did a sense that they led the country.

In addition, the Korean government allocated a substantial budget and supplied talented and technically trained bureaucrats to support other ministries and academic institutions. Proud to be regarded as experts, Korean high civil servants, especially those working at the economic planning board, were relatively free from influence from regional interests (e.g., kinship networks and school networks). The examination tested both general ability and knowledge as well as knowledge relevant to a particular job (Wilson, 1989). It was therefore a fair process that resulted in talented people being hired.

\section{Implementation Power}

Politicians enjoy announcing attractive policies that may turn out to be talk but no action because their concern is to appeal to voters and supporters. The bureaucracy, on the other hand, is the action-oriented sphere; it secures resources, produces agreement, 
and coordinates structures. Politicians' policy promises depend on bureaucrats if they are to become reality (Brunsson, 1989). Experienced politicians know that a good policy is useless if it is not implemented and that public opinion will turn against them if it is not. Without the bureaucracy, politicians cannot implement policy.

Bureaucrats are experts at implementing policies, which is a difficult process, since there can be inconsistency among different policies, a lack of legal support, a lack of money, and a lack of cooperation from the citizens. Street-level bureaucrats know exactly what is happening in their field, and they are better able than politicians to tell whether information is distorted or not.

Not only government officials but also professors and other experts also provided recommendations to the board for various economic and planning development projects for the implementation. The elite bureaucrats in the economic planning board's main role was to implement development plans and coordinate with other ministries in order to bring all related government agencies under its jurisdiction and to procure, manage, and allocate foreign capital, since there was not enough domestic capital. The board also held various forums designed to allow it to receive advice and support.

These processes associated with implementation created an opportunity to gather elites who were not part of the military regime together. Academic elites were able to perform their planning and budgetary roles under a fair and balanced approach with the overall economic framework in mind and relatively free from the control of the assembly and interest groups who were not sufficiently competent or trustworthy to make economic decisions.

\section{Proceduralism}

Democracy requires due process, which is the requirement that the state must respect all legal rights. In other words, a set of "procedures" makes democracy (Castoriadis, 1997). In his incisive critique of Prussian bureaucracy, Max Weber (1958) points out that Prussian politicians used parliamentary inquiries as a means to check on the progress of the administrative implementation of legislation. Such inquiries served as a proving ground for politicians in parliament. They would spar with administrative experts, seeking to show the supremacy of political decisions to an official's use of his education and skill to preserve the technical integrity of an administrative program. In case of Russia, there is a list of tables containing requirements that must be met for a policy to be implemented. Even if the leader or president wants to implement the policy, if the policy does not satisfy those requirements, it cannot be implemented. 
Administrative procedures include processes for making a collective decision inside the bureaucracy and the securing of documents in order to obtain authorizations and licenses. The complexity of these procedures is notoriously referred to as "red tape." Bozeman defines organizational red tape as "rules, regulations, and procedures that remain in force and entail a compliance burden for the organization but have no efficacy for the rules' functional object" (1993, p.283) In reality, however, red tape can be a positive force. It can protect bureaucrats from arbitrary requests, particularly in the semidemocratic countries. "Veto points" allow bureaucrats to resist external pressure. In the context of an authoritarian regime, collaborators with the dictator always attempt to bypass preset procedures. This is the reason why Van Loon et al. (2016) introduce a two-dimensional construct that includes a compliance burden and lack of functionality in order to measure the effects of red tape. Their findings show that red tape that has a high functionality is likely to produce good results even in developed countries.

The Korean government's economic development plan was not dictated by the president. Each economic planning board project featured a set of procedures that legally had to be followed. Development plans were carried out in three stages: a preparation stage, a sector-planning stage, and a consolidation and and finalization stage. During the first five-year plan (1962-1966), the supreme council for national reconstruction, the economic planning board (Overall Planning Bureau), and working-level committees all participated. During the second five-year plan (1967-1971), a series of cabinet council, joint committee, advisory committee, and sector-planning meetings were held. During the third five-year plan (1972-1976), the cabinet council, the deliberation council, the coordination committee, and sector-planning groups contributed to the economic development planning procedure. For the fourth plan (19771981), cabinet council, deliberation council, and working-level committee meetings were held. These meetings were open to the public to allow a national consensus to emerge. These kinds of procedures prevented influential politicians from capriciously intervening in the process.

\section{Rule of Law}

Weberian bureaucracy emphasizes the importance of rules and regulations for simplifying complex procedures and therefore strictly prohibits any action that breaks the law. Adherence to rules allows decisions made at high levels to be executed consistently by all lower levels. O'Donnell (2004) argues that "high-quality democracy requires a truly democratic rule of law that ensures political rights, civil liberties, and mechanisms of accountability which in turn affirm the political equality of all citizens 
and constrain potential abuses of state power" (p32). The rule of law "consists of the enforcement of laws that have been publicly promulgated and passed in a pre-established manner; are prospective, general, stable, clear and hierarchically ordered; and are applied to particular cases by courts independent from the political rulers and are open to all, whose decisions respond to procedural requirements, and that establish guilt through the ordinary trial process" (Maravall, 2003, p. 261).

The essential value of rule of law is its universal applicability. Not only the powerless but also people the powerful are obligated to follow the rules. In other words, laws are uncomfortable for dictators. More powerful individuals in developing countries are more likely to violate existing rules. For example, the rich and powerful families can avoid paying the income tax they owe, while the middle class is compelled to follow the rules and pay what they owe.

The bureaucrats who are in charge of implementing the law are the gatekeepers who can ensure the rule of law is followed. It is an uphill battle in most nondemocratic countries, but it is possible if bureaucrats are patient and start by applying the principle to the ordinary citizen. Gradually, once following the law becomes more accepted, there will be critical disjuncture between a powerful person and politicians.

\section{CONDITIONS OF BUREAUCRATIC DEMOCRATIZATION}

Not all bureaucracies are functional in the democratization of a country. A government bureaucracy can operate in favor of democratization or against it depending on conditions. The first condition for success is a strong bureaucracy. An unorganized bureaucracy in a country run by a dictator cannot democratize the country. The bureaucracy should be relatively big and intelligent. The second condition is the accumulation of its own power. In order to use bureaucracy as a tool for democratization, bureaucrats need to protect themselves from the arbitrary use of political authority and have autonomy (Im, 2007). Bureaucrats' neutral competence, which is their ability to do the work of government expertly (Kaufman 1956), also can help democratization. Heclo (1975) argues that bureaucrats can pursue neutral competence by bearing in mind the long-term, broader interests of the country and the government.

The bureaucracy should institutionalize red tape. A bureaucracy that operates too simply leaves itself vulnerable to the external pressure. Clear decision-making lines can be another requirement. Also, democratization can be aided when there is relative consensus about the goals government is pursuing and about the legitimacy of the agencies developed to pursue those goals and the laws authorizing agency actions. If tasks are easy to define and lines of authority are clear, bureaucrats can be neutral 
Figure 1. Summary Diagram

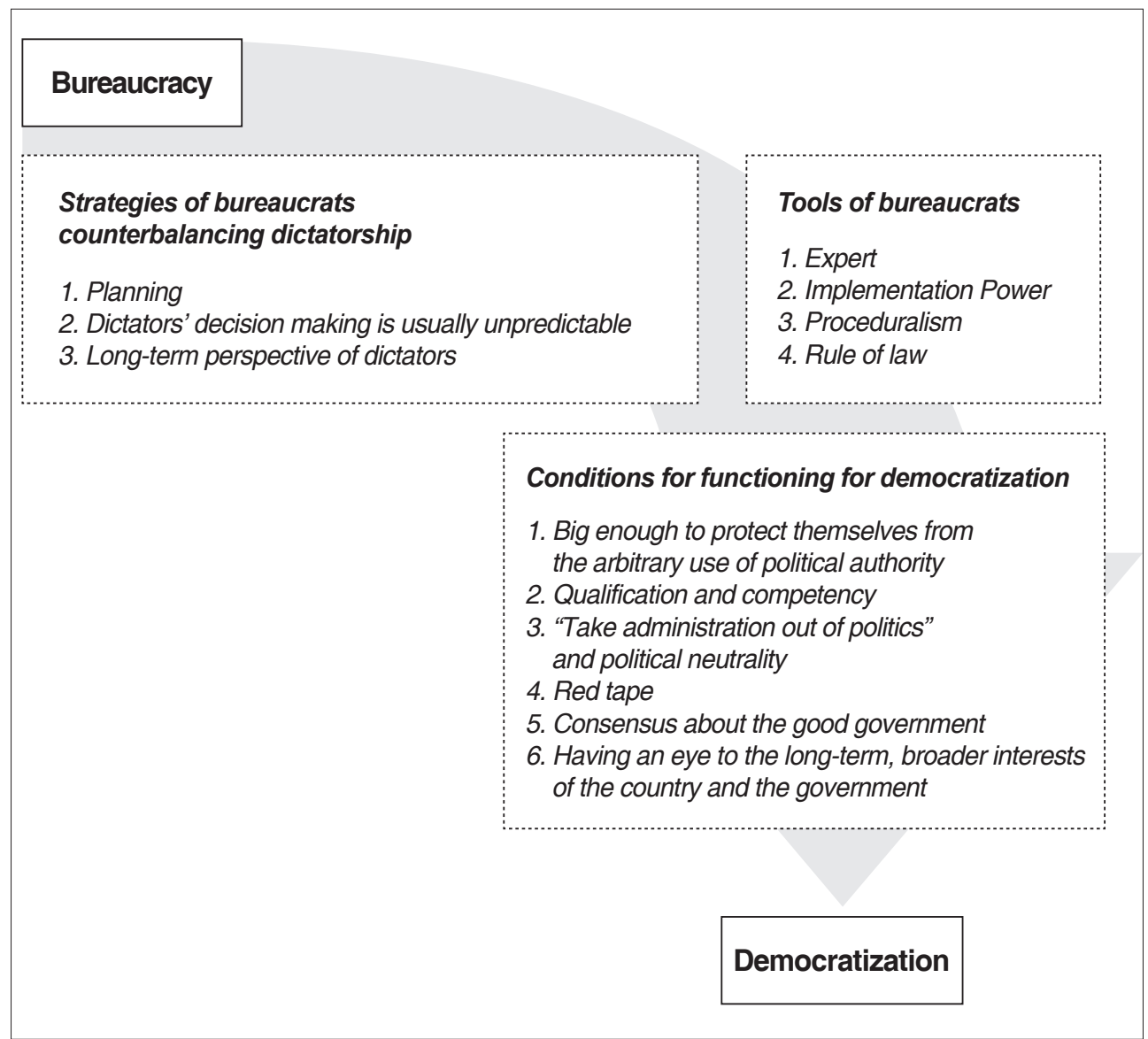

(Aberbach \& Rockman, 1994).

\section{CONCLUSION}

The main goal of this article is to attract attention to the role of bureaucracy in the process of democratization in developing countries. The suggestion that bureaucracy can contribute to democratization goes against the conventional theory of it, which claims that the chaos that tends to reign in developing countries is the result of politics and that therefore politics in the form of elections can fix the problem, as governance by elected officials, with help from NGOs, will increase transparency and due process. 
This idealistic line of reasoning also reflects the Marxist view in a sense, which proposes that after the proletarian revolution, a socialist society can be realized by democratic centralism, a form of government that can be found in China (and that was the form of government adopted by the former Soviet Union as well). However, the conventional view as well as Marxist view cannot explain what is happening in most developing countries. Elections are not the solution to the problem but the cause of problem itself. The "winner takes all" principle results in the exclusion of various social groups, whose position becomes desperate, intensifying an already undemocratic situation.

This is the reason why this study suggests focusing on bureaucracy. Bureaucracy need not just be a passive and neutral tool of the executive branch but can actively aid in the democratization of a country under certain conditions. Bureaucracy is a double-edged sword to the extent that it can be unpleasant for citizens to deal with, on the one hand, but can also protect them from arbitrary power, on the other.

Since democracy is the process of giving power back to people, the process varies according to the conditions of each country. Bureaucracy on the Weberian understanding of it has the potential to be a force for democracy. Bureaucracy can train people, collect knowledge, predict decisions, share goals and establish stable institutions staffed by knowledgeable experts that can counterbalance dictators or interest groups. Bureaucratic autonomy allows planning and the efficient implementation of policy in light of a country's unique context. Therefore, bureaucracy can be a positive driver, contributing to political democratization especially in developing countries.

\section{REFERENCES}

Aberbach, J. D., \& Rockman, B. A. 1994. Civil servants and policymakers: Neutral or responsive competence? Governance, 7(4): 461-469.

Albrow, M. 1978. Bureaucracy. London: Macmillan.

Almond, G. A. 1988. The return to the state. American Political Science Review, 82(3): 853-874.

Beetham, D. 1993. Beetham, D. 1993. Auditing Democracy in Britain. Democratic Audit Paper No. 1. Human Rights Centre, University of Essex, Colchester/ Charter 88 Trust, London

Beetham, D., \& Weir, S. 1999. Auditing British democracy, Political Quarterly, 70(2): 128.

Benveniste, G. 1983. Bureaucracy. San Fransisco, CA: Jossey-Bass.

Bozeman, B. 1993. A theory of government "red tape." Journal of Public Administra- 
tion Research and Theory, 3(3): 273-303.

Bozeman, B., \& Scott, P. 1996. Bureaucratic red tape and formalization: Untangling conceptual knots. American Review of Public Administration, 26(1): 1.

Brecht, A. 1954. How bureaucracies develop and function. Annals of the American Academy of Political and Social Science, 292(1): 1-10.

Brunsson, N. 1989. The organization of hypocrisy: Talk, decisions and actions in organizations. John Wiley \& Sons.

Brunsson, N. 2006. Administrative reforms as routines. Scandinavian Journal of Management, 22(3): 243.

Burton, M., R. Gunther and J. Higley. 1992 'Introduction: Elite Transformation and Democratic Regimes', in J. Higley and R. Gunther (eds) Elites and Democratic Consolidation in Latin America and Southern Europe, pp. 1-37. Boulder, CO: Rowman \& Littlefield

Bush, G. 1987. Review of Bureaucracy and democracy: A double dilemma, by Eva Etzioni- Halevy. Political Science, 39(2): 198-200.

Bäck, H., \& Hadenius, A. 2008. Democracy and state capacity: Exploring a J- shaped relationship. Governance, 21(1): 1-24.

Castoriadis, C. 1987. The imaginary institution of society. Trans. K. Blamey, Cambridge: Polity,.

Castoriadis, C. 1997. Democracy as procedure and democracy as regime. Constellations, 4(1): 1-18.

Chibber, V. 1999. Building a developmental state: The Korean case reconsidered (Economic policy and economic performance of South Korea). Politics and Society, 27(3): 309.

Chibber, V. 2002. Bureaucratic rationality and the developmental state. American Journal of Sociology, 107(4): 951-989.

Cho, W., Im, T., Porumbescu, G., Lee, H., \& Park, J. 2013. A cross-country study of the relationship between Weberian bureaucracy and government performance. International Review of Public Administration, 18(3): 115-138.

Choi, B. S. 1987. The structure of the economic policy-making institutions in Korea and the strategic role of the Economic Planning Board (EPB). Korean Journal of Policy Studies, vol.2, pp. 1-25

Dahl, R. A., \& Lindblom, C. E. 1963. Politics economics and welfare: Planning and politico-economic systems resolved into social processes / New York: Harper \& Row.

DeHart-Davis, L. 2005. Red tape and public employees: Does perceived rule dysfunction alienate managers? Journal of Public Administration Research and Theory, 15(1): 133-148. 
Dimock, M. E. 1959. Administrative vitality: The conflict with bureaucracy. New York: Harper and Brothers, 1959.

Du Gay, P, ed. The values of bureaucracy. OUP Oxford, 2005.

Edward, R. C. 1984. Forms of control in the labor process: An historical analysis. In C. Sirianni \& F. Fischer (eds.), Critical studies in organization and bureaucracy Rev. and exp. ed. Philadelphia: Temple University Press.

Etzioni-Halevy, E. 2010. Bureaucracy and democracy: A political dilemma. New York: Routledge.

Evans, P. B. 1985. Bringing the state back in. Cambridge: Cambridge University Press.

Evans, P. B., \& Rauch, J. E. 1999. Bureaucracy and growth: A cross-national analysis of the effects of "Weberian" state structures on economic growth. American Sociological Review, 64(5): 748-765.

Friedrich, C. 1963. Man and His Government. New York: McGraw-Hill Inc.

Gerth, H, \& Wright.M. 1958. Introduction to From Max Weber: Essays in sociology Trans. and ed. H. H. Gerth \& C. Wright Mills. New York: Oxford University Press

Goodsell, C. T. 1985. The case for bureaucracy: A public administration polemic: Chatham, NJ : Chatham House Publishers.

Grugel, J., \& Riggirozzi, P. 2012. Post-neoliberalism in Latin America: Rebuilding and reclaiming the state after crisis. Development and Change, 43(1): 1-21.

Hadenius, A. 1992. Democracy and Development, Cambridge: Cambridge University Press.

Haggard, S. 2004. Institutions and growth in East Asia. Studies in Comparative International Development, 38(4): 53-81.

Heclo, H. 1975. OMB and the presidency: The problem of neutral competence. Public Interest, 38: 80.

Higley, J., \& Gunther, R., eds. 1992. Elites and democratic consolidation in Latin America and southern Europe. New York: Cambridge University Press, 1992.

Holden B. 1988. Understanding Liberal Democracy, London: Sage

Im, T. 2007. Bureaucracy, Democracy and Market: Critique on 20 years' Government Reforms in Korea. Korean Public Administration Review. 41(3), 41-65.

Im, T. 2010. Does decentralization reform always increase economic growth? A cross-country comparison of the performance. International Journal of Public Administration, 33(10): 508-520.

Johnson, C. A. 1982. MITI and the Japanese miracle: The growth of industrial policy, 1925-1975. Stanford, CA: Stanford University Press, 1982.

Kaufman, H. 1956. Emerging conflicts in the doctrines of public administration. American Political Science Review, 50(4): 1057-1073. 
Kaufman, H. 1977. Red Tape: Its Origins, Uses, and Abuses. Washington, D.C.: Brookings.

Krasner, S. D. 1984. Approaches to the state: Alternative conceptions and historical dynamics. Comparative Politics, 16(2): 223-246.

Laski, H. J. 1930. Liberty in the modern state. London: Faber and Faber.

Lasswell, H \& Kaplan, A. 1963. Power and society: A framework for political inquiry. New Haven, CT: Yale University Press.

Lively, J. 1980. Democracy. Oxford, UK: Blackwell.

Maravall, J. M.. 2003. The rule of law as a political weapon. In A. Przeworski \& J. M Maravall (eds.), Democracy and the rule of law (pp. 261-301). New York: Cambridge University Press.

Mauro, P. 1995. Corruption and growth. Quarterly Journal of Economics, 110(3): 681.

Merton, R. K. 1940. Bureaucratic structure and personality. Social Forces, 18(4): 560568.

Miller, S. 1978. Bureaucracy baiting. American Scholar, 47(2): 205-222.

Muramatsu, M., \& Krauss, E. 1987. The Conservative Policy Line and the Development of Patterned Pluralism, 516-54. In Yamamura and Yasuba (eds). The Political Economy of Japan. Stanford, CA; Standord University Press

Nathan, R. 1976. The administrative presidency. Public Interest, 44: 40.

North, D. C. 1989. Institutions and economic growth: An historical introduction. World Development, 17(9): 1319-1332.

O’Donnell, G. 1982. Reply to Remmer and Merkx. Latin American Research Review, 17(2): 41.

O'Donnell, G. A. 2004. Why the rule of law matters. Journal of Democracy, 15(4): 32-46.

O’Donnell, G. A., \& Schmitter, P. C. 1986. Transitions from authoritarian rule: Tentative conclusions about uncertain democracies. Baltimore, MD: Johns Hopkins University Press.

Olsen, J. P. 2006. Maybe it is time to rediscover bureaucracy. Journal of Public Administration Research and Theory, 16(1): 1-24.

Przeworski, A. 2016. Democracy: A never-ending quest. Annual Review of Political Science, 19: 1-12.

Redford, Emmette Shelburn.1969. Democracy in the administrative state. New York: Oxford University Press,

Rodríguez-Pose, A., \& Ezcurra, R. 2011. Is fiscal decentralization harmful for economic growth? Evidence from the OECD countries. Journal of Economic Geography, 11(4): 619-643.

Ruostetsaari, Ilkka. Elite Recruitment and Coherence of the Inner Core of Power in 
Finland: Changing Patterns During the Economic Crises of 1991-2011. Lexington Books, 2015.

Remmer, K. L., \& Merkx, G. W. .1982.. Bureaucratic-authoritarianism revisited. Latin American Research Review, 17(2), 3-40.Ryan, A. 1970. The philosophy of the social sciences. New York: Pantheon.

Satori, G. 1962. Democratic theory. Detroit, MI: Wayne State University Press.

Saward, M. 1994. Democratic theory and indices of democratization. London: Sage.

Schumpeter, J. 1956. Capitalism, Socialism and Democracy, New York: Harper and Row.

Sen, A. 1999. Development as freedom. New York: Anchor Books.

Sharp, W. 1927. Le Développement de la Bureaucratie aux États-Unis, Revue des Sciences Politiques, vol. 50, p. 393-415,539-5

Shleifer, A., \& Vishny, R. 1993. Corruption. Quarterly Journal of Economics 108(3): 599-617.

Skocpol, T., Evans, P., \& Rueschemeyer, D. 1999. Bringing the state back in. Cambridge.

Stallings, B. 1990. The role of foreign capital in economic development. In G. Gereffi and D. L. Wyman (eds.), Manufacturing miracles: Paths of industrialization in Latin America and East Asia (pp. 55-89). Princeton, NJ: Princeton University Press.

Stepan, A. 2015. The state and society: Peru in comparative perspective: Princeton, NJ: Princeton University Press.

Thompson, Victor A. 1975. Without Sympathy or Enthusiasm: The Problem of Administrative Compassion, University, Alabama: The University of Alabama Press.

Timsit, G. 1991. Théorie de l'administration. Paris: Presses universitaires de France.

Van Loon, N, Leisink, P, Knies, E, \& Brewer, G. 2016. Red Tape: Developing and Validating a New Job-Centered Measure. Public Administration Review, 76(4), 662-673.

Weber, M. 1958. From Max Weber: Essays in sociology. Trans. and ed. H. H. Gerth and C. Wright Mills. New York: Oxford University Press.

Weber, M. 1968. Economy and society: An outline of interpretive sociology. New York: Bedminster Press.

Weber, M. 1978. The Protestant ethic and the spirit of capitalism. Trans. Talcott Parsons. New York: Scribners.

Wills, G. 2002. A necessary evil: A history of American distrust of government. New York: Simon and Schuster.

Wilson, J. Q. 1989. Bureaucracy: What government agencies do and why they do it. New York: Basic Books. 
